\title{
PELAKSANAAN e-MAR KETING USAHA MIKRO KECIL MENENGAH (UMKM) SEBAGAI STRAGI UNTUK MENINGKATKAN PENJUALAN (STUDI KASUS UMKM DI KOTA BENGKAYANG KALIMANTAN BARAT)
}

\author{
Blasius Manggu' ${ }^{1)}$ dan Sabinus Beni ${ }^{2}$ \\ ${ }^{1,2}$ Sekolah Tinggi Ilmu Manaajemen Shanti Bhuana \\ 1,2 Jl. Bukit Karmel No. 1 Bengkayang 79211 \\ E-mail : blasius@shantibhuana.ac.id ${ }^{1)}$, beni@shantibhuana.ac.id ${ }^{2)}$
}

\begin{abstract}
ABSTRAK
Pemasaaran merupakan segala kegiatan usaha yang berhubungan dengan penyerahan barang dan jasa dari produsen kepada konsumen. Sekarang ini pelaku usaha sudah banyak yang menerapkan sistem pemasaran secara online. Pemasaran melalui internet (internet marketing) atau lebih dikenal dengan nama e-marketing dapat menjangkau konsumen dimanapun berada. Belanja online yang saat ini diminati oleh masyarakat memberikan andil besar terhadap perkembangan e-marketing. Dengan menggunakan e-marketing kita dapat memperoleh keuntungan yang meliputi layanan konsumen dan layanan citra perusahaan menjadi baik, menemukan parnert bisnis baru, proses menjadi sederhana dan waktu dapat dipadatkan, dapat meningkatkan produktivitas, efisiensi, akses informasi menjadi cepat, belajar menarik dan berkomunikasi dengan pelanggan di situs jejaring sosial. Dengan dukungan internet e-Marketing mampu menjangkau pemasaran ruang lingkup yang lebih luas karena mengacu pada media digital seperti web, e-mail dan media nirkabel, meliputi pengolahan data pelanggan digital, dan juga bagaimana internet dapat digunakan bersama dengan media tradisional untuk memperoleh dan memberikan layanan kepada pelanggan Usaha Mikro Kecil Menengah merupakan salah satu bagian penting dari perekonomian suatu negara maupun daerah, begitu juga dengan Daerah Tingkat II Kabupaten Bengkayang Kalimantan Barat, Usaha Mikro Kecil Menengah memiliki peranan sangat penting dan merupakan salah sektor unggul dalam menopang pertumbuhan ekonomi ke arah yang lebih baik. Pelaksanaan e-Comerce menuntut pergeseran paradigma secara fundamental, dari yang semula marketplace yang menekankan interaksi secara fisik antara penjual dan pembeli menjadi marketspace, lalu lintas informasi, produk/jasa, dan pembayaran bersifat fisik (location based).
\end{abstract}

Kata Kunci: e-Marketing, Usaha Mikro Kecil Menengah, Strategi, Meningkatkan Penjualan

\section{PENDAHULUAN}

E-Comerce merupakan proses pembelian dan penjualan produk, jasa dan informasi yang dilakukan secara elektronik dengan memanfaatkan jaringan seperti radio, televisi, jaringan internet atau komputer. (Wong, 2010) memaparkan e-Marketing adalah sisi pemasaran dari e-comerce dan kepentingan khusus oleh pemasar yakni strategi proses pembuatan, pendistribusian, promosi dan penetapan harga barang atau jasa kepada pangsa pasar, melalui internet dan peralatan digital lainnya. Dengan dukungan internet e-Marketing mampu menjangkau pemasaran ruang lingkup yang lebih luas karena mengacu pada media digital seperti web, e-mail dan media nirkabel, meliputi pengolahan data pelanggan digital, dan juga bagaimana internet dapat digunakan bersama dengan media tradisional untuk memperoleh dan memberikan layanan kepada pelanggan (Chaffey, et al., 2000). e-Marketing menciptakan, berkomunikasi dan memberikan proses nilai kepada pelanggan yang menggunakan sistem teknologi informasi, dan untuk mengelola dan memelihara hubungan dengan pelanggan untuk mendapatkan manfaat bagi organisasi atau perusahaan dengan stakeholder. (Judy Strauss, 2009)
(K., 2015) Konsumen dapat dengan mudah mengetahui produk atau jasa yang diinginkannya tanpa harus ketempat penjualan atau pasar.

Internet dapat disebut sebagai jaringan alam yang sangat luas (Sibero, 2011). Selain itu, internet memudahkan gaya hidup manusia untuk memenuhi kebutuhan hidupnya dan meningkatkan produksi bisnis dalam memasarkannya melalui e commerce, diartikan sebagai suatu cara berbelanja atau berdagang secara on line atau direct selling yang memanfaatkan faslitas internet, dimana terdapat website yang dapat menyediakan layanan "Get and Deliver". (Kotler \& Amstrong, 2012) e-Marketing merupakan salah satu komponen dalam e-comerce dengan kepentingan khusus oleh pemasar, yakni strategi proses pembuatan, pendistribusian, promosi, dan penetapan harga barang atau jasa kepada pangsa pasar melalui internet dan peralatan digital lainnya. Electronic marketing memajukan program pemasaran yang mendukung tujuan-tujuan perusahaan melaksankan e-comerce. Menurut (Strauss \& Frost, 2009) Tujuh tahap dalam perancangan e-marketing adalah Situation Analysis (Analisis Situasi), e-Marketing Strategic Planning 
(Strategi Perencanaan E-Marketing), Objective (Tujuan), e-Marketing Strategy (Strategy e-Marketing), Implementation Plan (Rencana Pelaksanaan), Budget (Anggaran), Evaluation Plan (Rencana Evaluasi). Pelaksanaan e-Marketing bertujuan untuk (1) Meningkatkan pangsa pasar (2) Meningkatkan jumlah komentar pada sebuah blog atau website (3) Meningkatkan pendapatan penjualan (4) Mengurangi biaya (misalnya biaya distribusi atau promosi (5) Mencapai tujuan merk (seperti meningkatkan kesadaran merk) (6) Meningkatkan ukuran database (7) Mencapai tujuan Customer Relationship Management (CRM) (seperti meningkatkan kepuasan pelanggan, frekuensi pembelian, atau referensi pelanggan (7) Memperbaiki manajemen rantai suplai (seperti dengan meningkatkan koordinasi anggota, menambahkan mitra, atau mengoptimalkan tingkat persediaan

Media sosial berpotensi untuk membantu pelaku Usaha Mikro Kecil Menengah dalam memasarkan produknya (Stelzner, 2012). Media sosial didefinisikan sebagai kelompok aplikasi berbasis internet yang menciptakan fondasi ideologi dan teknologi dari web 2.0 yang memungkinkan penciptaan dan pertukaran user generated content (Chandra, 2010) Pemanfaatan eComerce diharapkan lebih luas sehingga mempermudah semua konsumen dari penjuru dunia, Pemanfaatan eComerce juga merupakan sebagai bentuk upaya inovasi pelayanan dari pemilik usaha kecil menengah kepada para konsumen atau pelanggan (Saputra, dkk, 2015).

Usaha Mikro Kecil Menengah (UMKM) telah menjadi bagian penting dari sistem perekonomian nasional yang mampu mempercepat pertumbuhan ekonomi melalui misi penyediaan lapangan usaha dan lapangan kerja, peningkatan pendapatan masyarakat, berperan dalam meningkatkan perolehan devisa serta memperkokoh struktur ekonomi masional (Hafni \& Rozali, 2017) disamping itu Usaha Mikro Kecil Menengah merupakan salah satu bagian penting dari perekonomian suatu negara maupun daerah, begitu juga dengan negara Indonesia Usaha Mikro Kecil Menengah sangat memiliki peranan penting dalam lajunya perekonomian masyarakat. Usaha Mikro Kecil Menengah juga sangat membantu negara/pemerintah dalam hal penciptaan lapangan kerja baru dan lewat Usaha Kecil Menengah juga banyak tercipta unit kerja baru yang menggunakan tenaga-tenaga baru yang dapat mendukung pendapatan rumah tangga. Selain dari itu Usaha Mikro Kecil Menengah juga memiliki fleksibilitas yang tinggi jika dibandingkan dengan usaha yang berkapasitas lebih besar. Usaha Mikro Kecil Menengah perlu perhatian yang khusus dan didukung oleh informasi yang akurat, agar terjadi link bisnis yang terarah atara para pelaku usaha kecil dan menengah dengan elemen daya saing, yaitu jaringan pasar.

Dalam perekonomian Indonesia, Usaha Mikro Kecil Menengah merupakan kelompok usaha yang memiliki jumlah paling besar dari kelompok usaha kecil maupun menengah. Hal ini dikarenakan, pelaku Usaha
Mikro Kecil Menengah dapat digerakkan atau dijalankan mulai dari kelas bawah hingga kelas atas. Disamping itu juga modal yang digunakan dalam pelaku Usaha Mikro Kecil Menengah tidaklah terlalu besar. Kriteria Usaha Mikro Kecil dan Menengah (UMKM) menurut UU Nomor 20 Tahun 2008, memiliki kriteria sebagai berikut: Usaha Mikro, yaitu usaha produktif milik orang perorangan atau badan usaha milik perorangan, yakni: ratus juta rupiah) Usaha Kecil, yaitu usaha ekonomi produktif yang berdiri sendiri dilakukan oleh orang perorangan atau badan usaha yang bukan merupakan anak perusahaan atau bukan cabang perusahaan yang dimiliki, dikuasai atau menjadi bagian baik langsung maupun tidak langsung dari usaha menengah atau usaha besar.

Selain berdasarkan Undang-Undang tersebut diatas, dari sudut perkembangannya (Rahmana, 2009) mengelompokkan Usaha Mikro Kecil Menengah dalam beberapa kriteria, yaitu (1) Livelihood Activities, merupakan Usaha Kecil Menengah yang digunakan sebagai kesempatan kerja untuk mencari nafkah, yang lebih umum di kenal sebagai sector informal. Contohnya adalah pedagang kaki lima. (2). Micro Enterprise, merupakan Usaha Kecil Menengah yang telah memiliki jiwa kewirausahaan dan mampu menerima pekerjaan sub kontrak dan ekspor. (3). Small Dynamic Enterprise, merupakan Usaha Kecil dan Menengah yang telah memiliki jiwa kewirausahaan dan mampu menerima pekerjaan sub kotrak dan ekspor. (4). Fast Moving Enterprise, merupakan Usaha Kecil Menengah yang telah memiliki jiwa kewirausahaan dan akan melakukan tranformasi menjadi Usaha Besar (UB).

Strategi digital marketing berpengaruh hingga $78 \%$ terhadap keunggulan bersaing Usaha Mikro Kecil Menengah dalam memasarkan produknya (Wardani, 2015) dalam jurnal penelitian itu dikemukakan 1 . Ketersediaan informasi produk dan panduan produk 2. Keteresediaan gambar gambar seperti poto atau ilustrasi produk. 3. Keteresediaan video yang mampu memvisualisasiakn produk atau menampilkan presentasi pendukung 4. Ketersediaan lampiran dokumen dokumen yang berisi informasi dalam berbagai format. 5 . Ketersediaan komunikasi online dengan pengusaha 6 . Ketersediaan alat transaksi dan variasi media pembayaran. 7. Ketersediaan bantuan dan layanan konsumen. 8. Ketersediaan tampilan testimonial 9. Ketersediaan catatan pengunjung 10. Ketersediaan penawaran khusus

Salah satu strategi yang dilakukan oleh pemerintah dalam menopang pembangunan ekonomi di kabupaten Bengkayang yaitu memberdayakan dan menumbuhkan usaha mikro, kecil dan menengah (UMKM) untuk meningkatkan sector unggul lokal. Begitu pentingnya permasalahan Usaha Mikro Kecil Menengah didalam meningkatkan penjualan. Tujuan penelitian ini dalah menghasilkan pelaksanaan strategi e-Marketing guna memberikan rekomendasi rujukan bagi Usaha Mikro Kecil Menengah. (Judy Strauss, 2009) (Totonchi \& 
Kakamanshadi, 2012) Dalam jurnal tersebut dikatakana bahwa dengan berkembangnya teknologi komunikasi akan berdampak pada pertumbuhan aktifitas yang siginifikan. Pernyataan ini juga disampaikan oleh (Putri \& Fitrah, 2017) dalam penelitian yang menyatakan bahwa ada pengaruh antara kampanye online marketing dengan kebiasaan konsumen dalam memilih suatu barang atau jasa Namum disisi lain, Usaha Mikro Kecil Menengah juga menghadapi banyak permasalahan, yaitu terbatasnya modal kerja, rendahnya kualitas Sumber Daya Manusia, dan kurangnya penguasaan ilmu pengetahuan dan teknologi, Usaha Mikro Kecil Menengah di Kabupaten Bengkayang meliputi Perdagangan, Hotel, Restoran, Keuangan, Persewaan dan Jasa Perusahaan, Bangunan, Industri Pengolahan, Pertanian, Peternakan, Kehutanan dan Perikanan.

\section{RUANG LINGKUP}

Dalam penelitian ini ruang lingkup permasalahan yang diteliti meliputi:

1. Bagaimana pelaksanaan e-Marketing Usaha Mikro Kecil Menengah di Kota Bengkayang dalam meningkatkan penjualan.

2. Membatasi pelaksanaan e-Marketing Usaha Mikro Kecil Menengah sebagai strategi dalam meningkatkan penjualan

3. Diharapkan melalui penelitian ini dapat diketahui strategi Usaha Mikro Kecil Menengah di Kota Bengkayang dalam meningkatkan penjualannya.

\section{BAHAN DAN METODE}

Berikut disajikan kajian teori dan metodologi dalam penelitian ini

\subsection{Kebijakan Pemasaran}

Pada umumnya didalam pemasaran dikenal empat kebijakan pokok yang biasa disebut 4P, yaitu (1) Kebijakan produk (Product) merupaan pemilihan yang seksama akan produk merupakan bagian yang penting. Pembeli baru mau membeli produk jika memang merasa tepat untuk membeli produk yang bersangkutan. Artinya produk yang menyesuaikan diri terhadap pembeli, bukan pembeli yang menyesuaikan diri terhadap produk. (2) Kebijakan Harga (Price) yaitu harga bagi sebagian besar masyarakat masih menduduki tempat terbatas, sebelum ia membeli barang dan jasa. Bagi penjual yang terpenting adalah bagaimana harga yang pantas, terjangkau oleh masyarakat dan tidak merugikan ke konsumen. (3) Kebijakan Saluran Distribusi (Place) yaitu harga bagi sebagian besar masyarakat masih menduduki tempat terbatas, sebelum ia membeli barang atau jasa. Bagi penjual yang terpenting adalah bagaimana menetapkan harga dan tidak merugikan pemasaran. (4) Kebijakan Promosi (Promotion) yaitu Suatu barang yang tidak serta merta langsung dikenal oleh masyarakat. Mungkin juga barang sudah lama tetapi sudah mulai dilupakan orang. Oleh sebab itu perlu dilakukan promosi karena promosi merupakan kegiatan untuk memperkenalkan dan meningkatkan kembali suatu produk, penjualan maupun pembuatanya.

\subsection{Potensi Sektor UMKM}

Sektor Usaha Mikro Kecil Menengah merupakan salah satu sektor yang penting dalam kegiatan perekonomian dan pengaruhnya sangat kuat terhadap perkembangan dan pertumbuhan perekonomian suatu wilayah. Kontribusi sektor Usaha Mikro Kecil Menengah terhahadap Product Domestic Bruto merupakan kontribusi yang paling besar dibandingkan sektor lainnya. Usaha Mikro Kecil Menengah merupakan usaha yang banyak dilakukan oleh pelaku usaha yang baru untuk memulai wirausaha dan perputaran usahanya sangat tergantung dari jenis barang yang diperdagangkan dan tipe penjualannya, sehingga perlu memperhatikan cash flow dan distribusinya dengan cara memperhatikan barang-barang dagangan mana saja yang lakunya cepat dan lambat.

\subsection{Strategi Pemasaran}

Strategi pemasaran merupakan alat fundamental yang dibuat guna mencapai tujuan bisnis atau perusahaan dengan meningkatkan kelebihan daya saing berkesinambungan (Tjiptono, 2015). Sementara itu, (Assauri, 2013) mendefinisikan strategi pemasaran adalah serangkaian tujuan dan sasaran, kebijakan dan aturan yang memberi arah kepada usaha-usaha pemasaran perusahaan dari waktu ke waktu, pada masing tingkatan dan acuan serta alokasinya, terutama sebagai tanggapan perusahaan dalam menghadapi lingkungan dan keadaan persaingan yang selalu berubah. Pada dasarnya strategi pemasaran memberikan arah dalam kaitannya dengan variabel-variabel seperti segmentasi pasar, identifikasi pasar sasaran, positioning, elemen bauran pemasaran dan biaya bauran pemasaran. Strategi pemasaran merupakan bagian integral dari strategi bisnis yang memberikan arah pada semua fungsi manajemen suatu organisasi. Strategi pemasaran terdiri atas lima elemen yang saling berkait, (Rumagia \& Utha, 2016) dalam jurnal Strategi dalam meningkatkan penjualan kacang kulit menyatakan bahwa elemen strategi terdiri dari lima yaitu (1) Pemilihan pasar, yaitu memilih pasar yang akan dilayani. (2) Perencanaan produk, meliputi produk spesifik yang dijual, pembentukan lini produk, dan desain penawaran individual pada masing-masing lini. Produk itu sendiri menawarkan manfaat total yang dapat diperoleh pelanggan dengan melakukan pembelian. Manfaat tersebut meliputi produk itu sendiri, nama merk produk, ketersediaan produk, jaminan atau garansi, jasa reparasi, dan bantuan teknisyang disediakan penjual, serta hubungan personal yang mungkin terbentuk diantara pembeli dan penjual. (3) Penetapan harga, yaitu menentukan harga yang dapat mencerminkan nilai kuantitatif dari produk kepada pelanggan. (4) Sistem distribusi, yaitu saluran perdagangan grosir dan eceran yang dilalui produk hingga mencapai konsumen akhir yang membeli dan menggunakannya. (5) Komunikasi 
pemasaran (promosi), yang meliputi periklanan, personal selling, promosi penjualan, direct marketing, dan public relations.

\subsection{Peningkatan Penjualan}

Penjualan bersih merupakan selisih antara penjualan baik yang dilakukan secara tunai maupun kredit dengan return penjualan dan potongan penjualan. (Sugiyono, 2009) Penjualan dibagi menjadi dua bagian : (1) Penjualan kredit, yaitu penjualan yang pembayarannya dilakukan dikemudian hari dalam jangka waktu yang telah ditetapkan setelah barang diterima customer. Penjualan kredit inilah yang menimbulkan piutang dagang, sehingga penjualan tidak dapat dipisahkan dari timbulnya piutang (2) Penjualan tunai, yaitu penjualan yang pembayarannnya dilakukan secara langsung saat terjadinya transaksi. Pengembangan ekonomi lokal merupakan proses yang mana pemerintah daerah dan atau kelompok berbasis komunitas mengelola sumberdaya yang ada dan masuk kepada penataan pekerjaan baru dengan sektor swasta, atau diantara mereka sendiri untuk menciptakan pekerjaan baru, dan merangsang kegiatan ekonomi wilayah dalam jurnal pengembangan ekonomi lokal partisipatif (masalah, kebijakan dan panduan pelaksana kegiatan) (Abdul Syakur) Selain itu, menurut (Etika Ari Susanti, Iman Hanafi, Romula Adionno) Pengembangan ekonomi lokal (PEL) adalah suatu proses dimana pemerintah lokal dan organisasi masyarakat terlibat untuk mendorong, merangsang, memelihara, aktivitas usaha untuk menciptakan lapangan pekerjaan. Jadi, pengembangan wilayah dilihat sebagai upaya pemerintah daerah bersama masyarakat dalam pengembangan kesempatankesempatan ekonomi yang cocok dengan SDM, dan mengoptimalkan pemanfaaatan sumber daya alam dan kelembagaan secara lokal.

Dalam keberhasilan pengembangan ekonomi lokal dapat dilihat dari beberapa indicator, (Husada, 2017) dalam jurnal strategi pengembangan ekonomi lokal menyatakan bahwa keberhasilan pengembangan ekonomi lokal (Husada, 2017) yaitu: (1) Perluasan kesempatan bagi masyarakat kecil dalam kesempatan kerja dan usaha; (2) Perluasaan bagi masyarakat untuk meningkatkan pendapataan; (3) Keberdayaan kelembagaan jaringan kerja kemitraan antara pemerintah, swasta, dan masyarakat lokal.

Dalam pertumbuhan ekonomi, bahwa investasi sumber daya manusia menjadi lebih penting peranannya dalam pembangunan. Sumber daya manusia yang berkualitas bagi negara sedang berkembang merupakan factor penting dalam upaya untuk mengejar ketertinggalan pembangunan dengan negara lain. Era informasi dan teknologi yang berkembang dewasa ini semakin membuktikan bahwa penguasaan, teknologi yang baik aku berdampak pada kualitas maupun kuantitas pembangunan itu sendiri. Agar teknologi dapat dikuasasi, maka dibutuhkan sumber daya manusia yang berkualitas. Dalam konteks proses produksi, maka adanya penguasaan teknologi yang baik, maka akan mendorong terjadinya inovasi teknologi. Inovasi teknologi tersebut pada akhirnya dapat menyebabkan penemuan produk produk baru.

\subsection{Metode}

Jenis penelitian yang dilakukan adalah penelitian kualitatif. Oleh karena itu, penelitian ini bersifat penelitian lapangan (field research. Dan penelitian ini termasuk dalam kategori field rasearch, karena dalam penelitian ini, peneliti terjun langsung ke lapangan untuk memperoleh data yang dibutuhkan. Tipe penlitian ini juga bersifat deskriptif, yakni metode yang meneliti status sekelompok manusia suatu objek, suatu kondisi, suatu sistem pemikiran pada saat masa sekarang. Tujuan penelitian deskriptif adalah membuat deskripsi gambaran secara sistematika, faktual dan akurat mengenai faktafakta, sifat serta hubungan antara fenomena yang diteliti. Dalam penelitian ini dapat memfokuskan masalah terlebih dahulu supaya tidak terjadi perluasan permasalahan yang nantinya tidak sesuai dengan tujuan penelitian ini. Maka peneliti memfokuskan untuk meneliti Usaha Mikro Kecil Menengah di Kota Bengkayang.

Tahapan dalam penelitian ini sebagai berikut

1. Identifikasi masalah, menganalisis masalah pada aspek pelaksanaan e-Marketing Usaha Mikro Kecil Menengah di Kota Bengkayang

2. Tujuan Penelitian, mengidentifikasi aspek yang berkaitan erat dengan permasalahan dalam pelaksanaan e-Marketing

3. Studi literatur,, kajian mendalam tentang pelaksanaan e Marketing, data data litearatur, baik jurnal maupun text book.

4. Pengolahan data, studi kelayakan mengenai aspek pelaksanaan e-Marketing, faktor yang dapat berpengaruh,

5. Analisis, menganalisis sejauh mana hasil pengolahan data pelaksanaan e-Marketing

6. Membuat kesimpulan berdasarkan hasil penelitian dan mmbuat saran.

Berikut ini disajikan bentuk bagan mengenai tahapan penelitian pada Gambar 1 . 


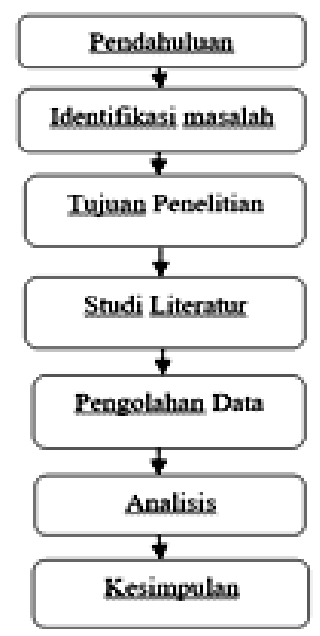

Gambar 1 Tahapan Penelitian

\section{PEMBAHASAN}

Strategi pemasaran merupakan suatu pola pikir yang dipakai untuk mengembangkan perusahaan. Cara yang diterapkan adalah dengan mengaitkan beberapa unsur pemasaran seperti segmentasi pasar, bauran marketing, posisi, sasaran dan sebagainya (Peter, 2016). Sementara itu, (Aaker, 2013) mendefinisikan strategi pemasaran sebagai suatu proses yang diawali dengan memindai lingkungan bisnis secara internal dan eksternal. Hal ini dilakukan dan dibutuhkan agara bisa memahami banyak aspek lingkungan eksternal agar bisa bersaing dengan fokus perhatian seperti ekonomi, teknologi, budaya, hukum, politik. Pada dasarnya strategi pemasaran memberikan arah dalam kaitannya dengan variabelvariabel seperti segmentasi pasar, identifikasi pasar sasaran, positioning, elemen bauran pemasaran dan biaya bauran pemasaran. Strategi pemasaran merupakan bagian integral dari strategi bisnis yang memberikan arah pada semua fungsi manajemen suatu organisasi. (Rumagia \& Utha, 2016) dalam jurnal Strategi dalam meningkatkan penjualan kacang kulit menyatakan bahwa elemen strategi terdiri dari lima yaitu (1) memilih pasar yang akan dilayani. (2) Perencanaan produk, meliputi produk spesifik yang dijual, pembentukan lini produk, dan desain penawaran individual pada masing-masing lini. Produk itu sendiri menawarkan manfaat total yang dapat diperoleh pelanggan dengan melakukan pembelian. Manfaat tersebut meliputi produk itu sendiri, nama merk produk, ketersediaan produk, jaminan atau garansi, jasa reparasi, dan bantuan teknisyang disediakan penjual, serta hubungan personal yang mungkin terbentuk diantara pembeli dan penjual. (3) Penetapan harga, yaitu menentukan harga yang dapat mencerminkan nilai kuantitatif dari produk kepada pelanggan. (4) Sistem distribusi, yaitu saluran perdagangan grosir dan eceran yang dilalui produk hingga mencapai konsumen akhir yang membeli dan menggunakannya. (5) Komunikasi pemasaran (promosi), yang meliputi periklanan, personal selling, promosi penjualan, direct marketing, dan public relations. Pada era digital, efektivitas dalam menggunakan social media marketing di indonesia sudah tidak diragukan lagi. Sosial media marketing memberi manfaat besar dalam meningkatkan brand awarenes, berikut ditunjukkan tingkat efektiftas digital marketing sumber media online. Tingkatan efektifitas digital marketing sumber media online disajikan pada Gambar 2.

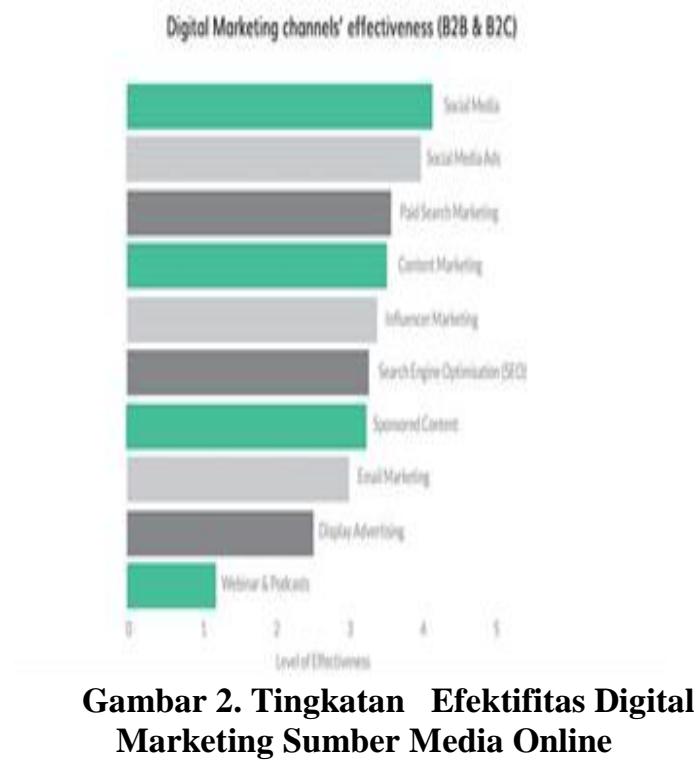

Dengan menerapkan e-Comerce kita dapat memperoleh keuntungan meliputi layanan konsumen dan citra perusahaan menjadi baik, menemukan parner bisnis baru, proses menjadi sederhana dan waktu dipadatkan, akses informasasi menjadi cepat, penggunaan kertas dapat dihindari. Pelaksanaan e-Comerce menuntut pergeseran paradigma secara fundamental, dari yang semula marketplace yang menekankan interaksi secara fisik antara penjual dan pembeli menjadi marketspace, lalu lintas informasi, produk/jasa, dan pembayaran bersifat fisik (location based) Pemasaran produk masih mengandalkan secara sederhana (pemasaran dari mulut ke mulut). Belum menjadikan media sosial atau jaringan internet sebagai alat pemasaran, keleihan e Marketing 1. Bisnis online bisa dijalankan dari mana saja, yang penting ada komputer atau laptop yang terhubung ke internet. 2. Modal yang dibutuhkan relatif lebih sedikit, 3. Bisnis bisa berjakan otomatis dengan bantuan sofware tertentu. 4. Tidak butuh jumlah karyawan yang banyak 5 . Tersedia banyak pilihan bisnis yang ada. Kekurangan eMarketing 1. Koneksi internet yang mahal. 2. Biaya yang tidak murah 3. Kurva pembelajaran lama, lebih banyak mengandalkan pengalaman pribadi untuk meraih kesuksesan bisnis online. 4. Awal-awal tahun akan banyak waktu daripada kerja biasa dan mengorbankan banyak waktu bersama keluarga. Belum dapat melibatkan lebih banyak tenaga kerja karena keterbatasan kemampuan financial sehingga kurang bersaing, pengelola belum dapat memisahkan antara 
uang untuk operasional rumah tangga dan usaha, terbatasnya sarana dan prasarana usaha terutama berhubungan dengan alat teknologi, keteraksesan internet masih merupakan hal yang mahal atau tidak cocok bagi pelanggan potensial, adanya keterbatasan akses internet di kota Bengkayang, Dukungan pemerintah masih sangat kurang dalam pengembangan Usaha Mikro Kecil Menengah di Kota Bengkayang, e-Marketing Usaha Mikro Kecil Menengah di Kota Bengkayang belum membawa dampak terhadap perkembangan peningkatan penjualan, perlu adanya pelatihan dan bimbingan dari pemerintah agar dapat meningkatkan persaingan dengan Usaha Mikro Kecil Menengah di daerah lain, melakukan inovasi dan variasi produk, lokasi usaha agar jangan saling berdekatan.

\section{KESIMPULAN}

Usaha Mikro Kecil Menengah memiliki peranan penting dalam lajunya perekonomian terutama di ekomomi tingkat lokal, Usaha Mikro Kecil Menengah di kabupaten Bengkayang masih belum menunjukan kontribusi yang yang dominan terhadap Produk Domestik Regional Bruto, keterbatasan sarana dan prasana, dukungan pemeritah yang masih sangat kurang, keterbatasan Sumber Daya Manusia yang masih rendah, kurangnya Sistem keamanan dan kehandalan, standard dan beberapa protocol komunikasi, adanya bandwidth telekomunikasi yang tidak mencukupi, adanya pengembangan perangkat lunak masih dalam tahap perkembangan dan berubah dengan cepat, sulit menyatukan perangkat lunak internet dan e-Comerce dengan aplikasi dan database yang sekarang ini, akses teknologi informasi yang masih minim, pemasaran Usaha Mikro Kecil Menengah sebagian masih menggunakan cara tradisional, komunikasi dan promosi yang dilakukan masih jauh dari sentuhan modern mengakibatkan kurangnya berkompetisi dalam meraih pangsa pasar mengakibatkan penuruan penjualan.

\section{SARAN}

Sehubungan dengan peranan Usaha Mikro Kecil Menengah dalam perekonomian ditingkat lokal, khususnya di kabupaten bengkayang masih belum menunjukan kontribusi yang tinggi, maka diharapkan peran serta pemerintah dalam mendukung Usaha Mikro Kecil Menengah terutama dalam membangun sarana dan prasarana yang cukup memadai, pelatihan dan pengembangan Sumber Daya Manusia sehigga mampu bersaing dengan daerah lain, cara memasarkan Usaha Mikro Kecil Menengah perlu adanya sentuhan teknologi, dorongan Akses teknologi informasi bagi para pelaku Usaha Mikro Kecil Menengah di tingkatkan.

\section{DAFTAR PUSTAKA}

Aaker, D., 2013. Manajemen Pemasaran Strategi. Delapan ed. Jakarta: Salemba Empat.

Assauri, S., 2013. Strategic Marketing: Suistaining
Liferime Costumer Value. Jakarta: Gramedia Pustaka Utama.

Chaffey, D., Richard, M. \& Kevin Johnston, D. F. E. C., 2000. Internet Marketig, Strategi, Implementation and Practice. Limited ed. London: Pearson Education .

Chandra, A., 2010. e-Bisnis \& e Commerce. 1 ed. Yogyakarta: ANDI.

Hafni, R. \& Rozali, A., 2017. Analisis Usaha Mikro Kecil dan Menengah (UMKM) Terhadap Penyerapan Tenaga Kerja di Indonesia. Jurnal Umsu, p. 134.

Husada, B., 2017. Strategi Pengembangan Ekonomi Lokal Kabupten Lampung Timur. Jurnal Derivati FE UMM Lampung, II No. 1(Ekonomi Loka), pp. 1-8.

Kotler, P. \& Amstrong, G., 2012. Dasar-Dasar Pemasaran: Alih Bahasa Alex Sindoro. 9 ed. Jakarta: Indeks.

Peter, P. J., 2016. Prilaku Konsumen Dan Strategi Pemasaran. Baru ed. Jakarta: Salemba Empat.

Putri, S. \& Fitrah, D., 2017. Pengaruh online marketing campaign\#samyangchallenge terhadap consumer behavior digital natives pengguna youtobe Indonesia. Jurnal Profesi Humas, 1(Onlie Marketing), pp. 132-134.

Rahmana, A., 2009. Peranan Teknologi Informasi Dalam Meningkatkan Daya Saing Usaha Kecil Menengah, Seminar Nasional Teknologi Informasi. http// Journal UII, Issue UMKM Berbasis Teknologi Informasi.

Rumagia, S. R. \& Utha, A., 2016. Strategi Pemasaran Dalam Meningkatkan Penjualan Kacang Kulit Garuda Food. Ilmu Administrasi Bisnis Universita Halu Oleo, --(Strategi Marketing), p. 212.

Saputra, D. \&. F. D., 2014. Sistem Informasi Pencatatan Hutang Piutang Pada Usaha Mikro Kecil Menengah (Studi Kasus, Bungo Sahabat). Pro Bisnis, 1(Akuntansi), p. 7.

Sibero, A., 2011. Kitab Suci Programing. Yogyakarta: Mediakom.

Stelzner, M., 2012. How Marketers Are Using Social Media To Grow Their Busines. London: Pearson Education.

Strauss, J. \& Frost, R., 2009. e-Marketing. Seventh ed. Ohio: Pearson.

Sugiyono, 2009. Metode Penelitian Kuantitatif, Kualitatif \& R.D. Bandung: Alfabeta.

Susanti, E. A., Hanafi, I. \& Adiono, R., 2015. Pengembangan Ekonomi Lokal Dalam Sektor Pertania. Administrasi Publik, 1 No. 4(Ekonomi Lokal), pp. 31-44.

Syakur, A., 2015. Siti Rahmania Rumaga, Arifin Utha dalam jurnal Strategi dalam meningkatkan penjualan kacang kulit menyatakan bahwa elemen strategi terdiri dari lima yaitu. Media Neliti.com, --(Ekonomi 
Lokal), pp. 131-144.

Tjiptono, F., 2015. Strategi Pemasaran. Yogyakarta: Andy Publisher.

Totonchi, J. \& Kakamanshadi, G., 2012. Relationship Between Globalization and EComerce. International Journal of $e$ Education, e Business, e Management and eLearning, 2 No. 1(e Commerce), pp. -.

Wardani, K., 2015. Analisis Pola Persebaran Spesial Usaha Mikro Kecil dan Menengah (UMKM) di Kabupaten Sukoharjo. UNS, 6 No. 2(Digital UMKM), pp. 25-30.

Wong, J., 2010. Internet Marketing For Beginners. Jakarta: Elex Media Komputindo.

\section{UCAPAN TERIMA KASIH}

Ucapan terima kasih diberikan kepada Institusi Sekolah Tinggi Ilmu Manajemen Shanti Bhuana atas bantuannya baik dalam bentuk moral maupun dalam bentuk materi, sehingga penelitian ini dapat berjalan dengan lancar dan dapat terselesaikan.

Terima kasih juga diberikan kepada penulis kedua atas bantuannya dalam proses dan penyusunan penelitian ini. 